\title{
"Let's Talk About What Just Happened": a Single-Site Survey Study of a Microaggression Response Workshop for Internal Medicine Residents
}

J Gen Intern Med 36(11):3592-4

DOI: $10.1007 / \mathrm{s} 11606-020-06576-6$

(C) Society of General Internal Medicine 2021

\section{INTRODUCTION}

Microaggressions, defined as verbal, behavioral, or environmental communications that convey hostility, invalidation, or insult based on an individual's marginalized status in society, are ubiquitous in health care and medical training. ${ }^{1,2}$ Emerging data from medical trainees have shown an association between the frequency of mistreatment and feelings of burnout and suicidal thoughts. ${ }^{1}$ Microaggressions are difficult to respond to, especially for trainees who are learning to maintain therapeutic alliances, balance principles of medical ethics, and negotiate medical hierarchies. There are growing calls to incorporate practical training on responding to microaggressions into medical education. ${ }^{3-5}$ In this study, we describe a microaggression response toolkit (MRT) and workshop for residents, and their effects on perceived abilities to identify and respond to microaggressions.

\section{METHOD}

Based on literature and in consultation with a resident working group, we developed the MRT to describe strategies for responding to microaggressions as a target or witness (Fig. $1)^{2,4-6} \mathrm{We}$ designed a fifty-minute workshop for internal medicine residents based on the MRT and informed by concurrent trainings at the associated medical school ${ }^{3}$ with the following goals: identify microaggressions using case scenarios, describe the impact of microaggressions on provider wellbeing and learning environments, and practice response strategies through role plays. Case scenarios and role play prompts were developed using published qualitative research and resident-reported microaggressions.

Prior Presentations Poster presentation, Society of Hospital Medicine Annual Conference, April 2020; and oral presentation, Society of General Internal Medicine Annual Meeting, May 2020. Presentations were scheduled then cancelled because of COVID-19 travel and meeting bans. Abstracts were included in conference publications.

Received July 27, 2020

Accepted December 29, 2020

Published online January 21, 2021
We performed electronic pre- and post-surveys to assess the utility of the workshop. Participants were asked to assess their comfort identifying microaggressions $(1=$ not at all comfortable, $5=$ very comfortable); understanding of the potential impact of microaggressions $(1=$ do not understand, $5=$ fully understand); and confidence in responding to microaggressions $(1=$ not at all confident, $5=$ very confident $)$. They were asked about the perceived importance of microaggression training and its value. They had the option to provide additional comments and make suggestions for improvement. Survey completion was voluntary and anonymous with no compensation.

\section{RESULTS}

The workshop was delivered during three sessions to 85 residents total (79\% of approximately 107 eligible residents; 15 to 40 residents per session) of mixed post-graduate years (PGY1-PGY3) during March and April 2019, as part of a retreat and a noon conference series; participation was highly encouraged but not mandatory. It was facilitated by a senior resident (HF) with faculty mentor support (PC, JS, MAY). There were 55 responses to the pre-workshop (65\% response rate) and 37 responses to the post-workshop surveys ( $44 \%$ response rate).

We calculated the percentage of respondents who reported a 4 or 5 on Likert scales described above. After the workshop, residents reported increased comfort with identifying microaggressions ( $29 \%$ pre-survey vs $89 \%$ post-survey selected "comfortable" or "very comfortable"), improved understanding of the impact of microaggressions (62\% pre-survey vs $97 \%$ post-survey selected "understand" or "fully understand"), and increased confidence in responding to microaggressions ( $13 \%$ pre-survey vs $70 \%$ post-survey selected "confident" or "very confident"). On the pre-survey, $75 \%$ of residents agreed or strongly agreed that training on microaggressions should be part of the curriculum. On the post-survey, $97 \%$ of responding residents agreed or strongly agreed that the workshop was a worthwhile use of time. Residents frequently cited the MRT and practice scenarios as the best part of the workshop. For improvement, they suggested providing more time for discussion and incorporating more complex microaggression scenarios. 
Microaggression Response Toolkit

To be combined and adapted as needed for each person and situation

\begin{tabular}{|c|c|c|}
\hline Response Strategy & Description & - Sample language \\
\hline $\begin{array}{l}\text { Practice } \\
\text { MicroAffirmations }\end{array}$ & $\begin{array}{l}\text { Behave positively in ways that } \\
\text { counter a microaggression; } \\
\text { communicate respect, promote } \\
\text { another persons' ideas, or recognize } \\
\text { their contributions. }\end{array}$ & $\begin{array}{l}\text { - "X is an exceptionally trained medical professional and we are } \\
\text { lucky to have her on our team." } \\
\text { - "I'd like to listen to what X was saying." } \\
\text { - "X had a great idea. Will you share that with us again?" }\end{array}$ \\
\hline Assume best intent & $\begin{array}{l}\text { Underlying principle is separating } \\
\text { intent from impact. Can involve } \\
\text { explicit appeal to common values. }\end{array}$ & $\begin{array}{l}\text { - "It sounds like you intended to compliment X, however that } \\
\text { comment can also imply that__." } \\
\text { - "I know you really care about___. Acting in this way undermines } \\
\text { those intentions." }\end{array}$ \\
\hline State your take & $\begin{array}{l}\text { Share your experience objectively, } \\
\text { without apologies or accusations, } \\
\text { then state what those facts mean to } \\
\text { you and invite others to discuss. }\end{array}$ & $\begin{array}{l}\text { - "I felt _ when I heard/saw/learned ___ and it ___ (describe } \\
\text { impact on you)." } \\
\text { - "I was so upset by that remark that I shut down and couldn't pay } \\
\text { attention to anything else. What did other people experience?" }\end{array}$ \\
\hline Depersonalize & $\begin{array}{l}\text { Use objective non-personal } \\
\text { statements to describe what is } \\
\text { occurring. }\end{array}$ & $\begin{array}{l}\text { - "I notice you are speaking negatively about other groups of } \\
\text { people." } \\
\text { " "We are not giving everyone an opportunity to contribute to this } \\
\text { conversation." }\end{array}$ \\
\hline Get curious & $\begin{array}{l}\text { Inquire about another person's } \\
\text { perspective or intended impact. } \\
\text { Provides opportunity for person to } \\
\text { self-correct or to engage in dialogue. }\end{array}$ & $\begin{array}{l}\text { - "Can you say more about that?" } \\
\text { - "I'm curious. What makes you say that?" } \\
\text { - "Can you help me understand what you meant by that?" } \\
\text { - "Will you tell me more about what was going on?" }\end{array}$ \\
\hline Repeat/reflect & $\begin{array}{l}\text { Repeat back verbatim or paraphrase. } \\
\text { Conveys respect for person and } \\
\text { relationship and provides opportunity } \\
\text { for reflection and self-correction. }\end{array}$ & $\begin{array}{l}\text { - "I think I heard you say __. Is that correct?" } \\
\text { - "It sounds like you believe __. "I hear you saying that __. Do I have that right?" }\end{array}$ \\
\hline Reframe & $\begin{array}{l}\text { Use hypotheticals or strategic } \\
\text { questions to empower the receiver to } \\
\text { reflect and decrease defensiveness }\end{array}$ & $\begin{array}{l}\text { - "Could there be another way to look at this situation?" } \\
\text { - "What would happen if } \\
\text { - "How do you think this interaction would be different if }\end{array}$ \\
\hline Redirect & $\begin{array}{l}\text { Shift the focus to a different person or } \\
\text { a different topic. }\end{array}$ & $\begin{array}{l}\text { - "Let's shift the conversation to _(other topic)." } \\
\text { - "I'd like to hear what others have to say" }\end{array}$ \\
\hline $\begin{array}{l}\text { Use preference } \\
\text { statements }\end{array}$ & $\begin{array}{l}\text { Clearly state what you would prefer in } \\
\text { the future. }\end{array}$ & $\begin{array}{l}\text { - "It would be helpful for me if we limit our conversation to your } \\
\text { medical problems" } \\
\text { - "I would like all team members to be spoken to with respect" }\end{array}$ \\
\hline Set boundaries & $\begin{array}{l}\text { Name the behavior and set a clear } \\
\text { limit to what you will tolerate. }\end{array}$ & $\begin{array}{l}\text { - "We don't tolerate negative comments about people's } \\
\text { race/ethnicity/gender here" } \\
\text { - "I care about you as a person, but I will not tolerate offensive } \\
\text { language or behavior. Now, let's focus on } \\
\text { - "I don't think that joke was funny. Please stop." }\end{array}$ \\
\hline Disengage & $\begin{array}{l}\text { Extract yourself from a situation that } \\
\text { is harmful and/or not productive. }\end{array}$ & $\begin{array}{l}\text { - "This is not a productive conversation right now. I will return } \\
\text { later when we both are calmer" } \\
\text { - "Excuse me, I need to go discuss this with one of my supervising } \\
\text { physicians." } \\
\text { - "I don't feel comfortable. I am going to leave now." }\end{array}$ \\
\hline Debrief & $\begin{array}{l}\text { Discuss with others after the event. } \\
\text { Especially important if you are the } \\
\text { leader or most senior member of a } \\
\text { group. }\end{array}$ & $\begin{array}{l}\text { - "Let's talk about what just happened." } \\
\text { - "That was a very difficult situation. It is important to me that we } \\
\text { have a chance to debrief as a group." } \\
\text { - "Would anyone like to share their reactions/thoughts/feelings?" }\end{array}$ \\
\hline Revisit & $\begin{array}{l}\text { Return for discussion or response } \\
\text { with person who committed } \\
\text { microaggression at a later time when } \\
\text { you have had opportunity to reflect } \\
\text { and prepare. }\end{array}$ & $\begin{array}{l}\text { - "I want to discuss something that happened yesterday." } \\
\text { - "I have been thinking about your comment last week about __. } \\
\text { I wanted to say _.." }\end{array}$ \\
\hline
\end{tabular}

Figure 1 Microaggression response toolkit. ${ }^{2,4-6}$

\section{DISCUSSION}

In this study, we found that participation in a brief, practical workshop on microaggressions using the MRT was associated with improvements in self-reported comfort in identifying microaggressions, understanding of their impacts, and confidence in responding to them.

Limitations of this study include the small sample size, selection bias in participating residents, the low survey response rate with variable response rates by group size, single-site application, and the use of self-reported outcomes. Future work is needed to determine the durability of benefits and whether residents' perceived comfort with addressing microaggressions translates into real-world experiences.

The MRT could be easily disseminated to other institutions, delivered at the different levels of medical education, and adapted for interprofessional providers. By increasing knowledge and self-efficacy around management of microaggressions, we may be better able to mitigate microaggressions' noxious effects. This is especially important as we respond to a global pandemic and for reaffirming commitments to a culture of equity, inclusion, and trust. 
Herrick N. Fisher, MD MPhil ${ }^{1,2}$

Paula Chatterjee, MD MPH ${ }^{3,4}$

Jo Shapiro, $M D^{2,5}$

Joel T. Katz, $M D^{1,2}$

Maria A. Yialamas, $M D^{1,2}$

${ }^{1}$ Department of Medicine, Brigham \& Women's Hospital,

Boston, MA, USA

${ }^{2}$ Harvard Medical School,

Boston, USA

${ }^{3}$ Division of General Internal Medicine, Perelman School of Medicine at the University of Pennsylvania,

Philadelphia, PA, USA

${ }^{4}$ Leonard Davis Institute for Health Economics, Philadelphia, PA, USA

${ }^{5}$ Department of Anesthesia, Pain and Critical Care, Massachusetts General Hospital,

Boston, MA, USA

Corresponding Author: Herrick N. Fisher, MD MPhil; Department of Medicine, Brigham \& Women's Hospital, Boston, MA, USA (e-mail: hnfisher@bwh.harvard.edu).

Author's Contribution Tamara Feingold-Link, MD; Sunny Kung, MD; Allison Vise, MD; Yan Yuan, MD; and Rebecca Zon, MD, for their work on the Microaggression Response Initiative. Raquel Sofia Sandoval; Titlayo Afolabi; Jordan Said; Spencer Dunleavy, MSc; Avik Chatterjee, MD MPH; and Daniele Ölveczky, MD MS, for faculty development as part of a medical student microaggression training.

\section{Compliance with Ethical Standards:}

Conflict of Interest: The authors have no conflicts of interest.

\section{REFERENCES}

1. Hu Y-Y, Ellis RJ, Hewitt DB, et al. Discrimination, Abuse, Harassment, and Burnout in Surgical Residency Training. N Engl J Med. 2019;381(18):1741-1752. doi:https://doi.org/10.1056/NEJMsa1903759

2. Torres MB, Salles A, Cochran A. Recognizing and Reacting to Microaggressions in Medicine and Surgery. JAMA Surg. 2019;154(9):868. doi:https://doi.org/10.1001/jamasurg.2019.1648

3. Sandoval RS, Afolabi T, Said J, Dunleavy S, Chatterjee A, Ölveczky D. Building a Tool Kit for Medical and Dental Students: Addressing Microaggressions and Discrimination on the Wards. MedEdPORTAL. 2020;16(1):mep_2374-8265.10893. doi:https://doi.org/10.15766/mep_ 2374-8265.10893

4. Shankar M, Albert T, Yee N, Overland M. Approaches for Residents to Address Problematic Patient Behavior: Before, During, and After the Clinical Encounter. J Grad Med Educ. 2019;11(4):371-374. doi:https:// doi.org/10.4300/JGME-D-19-00075.1

5. Wheeler DJ, Zapata J, Davis D, Chou C. Twelve tips for responding to microaggressions and overt discrimination: When the patient offends the learner. Med Teach. Published online October 2, 2018:1-6. https://doi. org/10.1080/0142159X.2018.1506097

6. Sue DW, Alsaidi S, Awad MN, Glaeser E, Calle CZ, Mendez N. Disarming racial microaggressions: Microintervention strategies for targets, White allies, and bystanders. Am Psychol. 2019;74(1):128-142. doi:https://doi. org/10.1037/amp0000296

Publisher's Note: Springer Nature remains neutral with regard to jurisdictional claims in published maps and institutional affiliations. 